\title{
As a Rare Reason of Alveolar Consolidation, Negative Pressure Pulmonary Edema: Case Report
}

\section{Nadir Bir Alveolar Konsolidasyon Nedeni Olarak, Negatif Basınçlı Akciğer Ödemi: Olgu Sunumu}

\section{Muhammet Ahmet KARAKAYA $\odot$, Afak Durur KARAKAYA $\odot$}

Ethics Committee Approval: Approval

Conflict of Interest: The authors declare that they have no conflict of interest.

Funding: None.

Informed Concent: Informed consent was taken.
Cite as: Karakaya MA, Karakaya AD. As a rare reason of alveolar consolidation, negative pressure pulmonary edema: case report. Medeniyet Med J. 2020;35:75-8.

\begin{abstract}
In this paper we describe two cases with negative pressure pulmonary edema (NPPE). Excessive negative airway pressures against an obstructed airway has been reported to cause fluid filtration into alveoli and lung edema. The patients are generally young adults without any medical problems. The condition involves central interstitial area of both lungs and is treated by nonnvasive mechanical ventilation and corticosteroids.

Keywords: Pulmonary edema, computed tomography, alveolar consolidation

Öz

Bu yazıda negatif basınçlı akciğer ödemi (NPPE) olan iki olgu tanımlanmıştır. Tıkalı bir hava yoluna karşı, aşırı negatif hava yolu basıncının alveollerde ve akciğerde ödeme neden olduğu bildirilmiştir. Hastalar genellikle herhangi bir tıbbi problemi olmayan genç yetişkinlerdir. Bu durum, her iki akciğerin santral interstisyel bölgesini içerir ve noninvaziv mekanik ventilasyon ve kortikosteroidlerle tedavi edilir.
\end{abstract}

Anahtar kelimeler: Akciğer ödemi, bilgisayarlı tomografi, alveolar konsolidasyon
Received: 25 November 2020

Accepted: 25 February 2020

Online First: 28 February 2020

Corresponding Author: A.D. Karakaya ORCID: 0000-0003-3604-6791 Koc University, Department of Radiology, Istanbul, Turkey

afkarakaya@kuh.ku.edu.tr

M.A. Karakaya ORCID: 0000-0001-8026-4783 Koc University, Department of Anesthesiology and Reanimation, Istanbul, Turkey 


\section{INTRODUCTION}

Negative pressure pulmonary edema (NPPE) is a rare reason of acute respiratory failure and alveolar consolidation. In patients with NPPE, there are patchy non-segmental alveolar consolidations in central distribution on CT. In alveolar pattern, filling of the alveolar spaces with pus, edema, hemorrhage, inflammation or tumor cells are seen. NPPE is one of the illnesses which induces an alveolar pattern. In this paper, we aimed to present two patients who developed acute respiratory failure due to NPLE after general anesthesia.

\section{CASE 1}

A 25-year-old man was admitted to our hospital due to perianal abscess and operated. His BMI was $27 \mathrm{klg} / \mathrm{m}^{2}$ and he had ASA II score due to anemia. Preoperatively, his chest examination results were normal, and a chest radiograph indicated clear lung fields. Standard monitorization of the patient was performed with electrocardiogram, noninvasive arterial blood pressure measurement and pulse oximetry. According to anesthesia induction protocol, $1.5 \mu \mathrm{g} / \mathrm{kg}$ fentanyl, $2 \mathrm{mg} / \mathrm{kg}$ propofol and $1 \mathrm{mg} / \mathrm{kg}$ rocuronium bromide were used after satisfactory muscular relaxation an orotracheal intubation was performed with an 8-mmthick cuffed tube. The patient was ventilated with a $550 \mathrm{ml}$ tidal volume in order to ensure 14 respirations per minute in a volume control mode. The respiratory parameters were set in order to have a $\mathrm{CO}_{2}$ end-tidal level between 35-40 mmHg. Anesthesia was maintained by providing fresh gas of $1-2 \%$ minimally alveolar consolidation (MAC) sevoflurane and $50 \% \mathrm{O}_{2}$-air with $3 \mathrm{~L} / \mathrm{min}$. The surgery lasted for about 60 minutes. In the operation, $800 \mathrm{~mL}$ crystalloid $(0.9 \% \mathrm{NaCl})$ infusion was made. The procedure was terminated without any complications. When enough respiratory depth was reached, severe agitation, laryngospasm and inspiratory effort developed following extubation. Negative pressure pulmonary edema was suspected due to the presence of foamy, pink colored, bloody secretion, auscultating common rales in both lungs, and oxygen-free saturation values of 86 percent. The patient was given oxygen and taken to intensive care unit for postoperative follow-up. In the first blood gas sample taken in the intensive care unit, $\mathrm{pH}$ was measured as $7.32, \mathrm{pO}_{2}$ : $53 \mathrm{mmHg}, \mathrm{pCO}_{2}: 33 \mathrm{mmHg}, \mathrm{HCO}_{3}$ : $18 \mathrm{mmol} / \mathrm{L}$ Lactate: $1.2 \mathrm{mmol} / \mathrm{L}$. The patient did not need intubation and we performed NIMV with pressure mode and PEEP (positive end-expiratory pressure). In computed tomography of the patient, there were ground-glass opacifications and alveolar consolidations which were denser in the central interstitial area of both lungs. Noninvasive

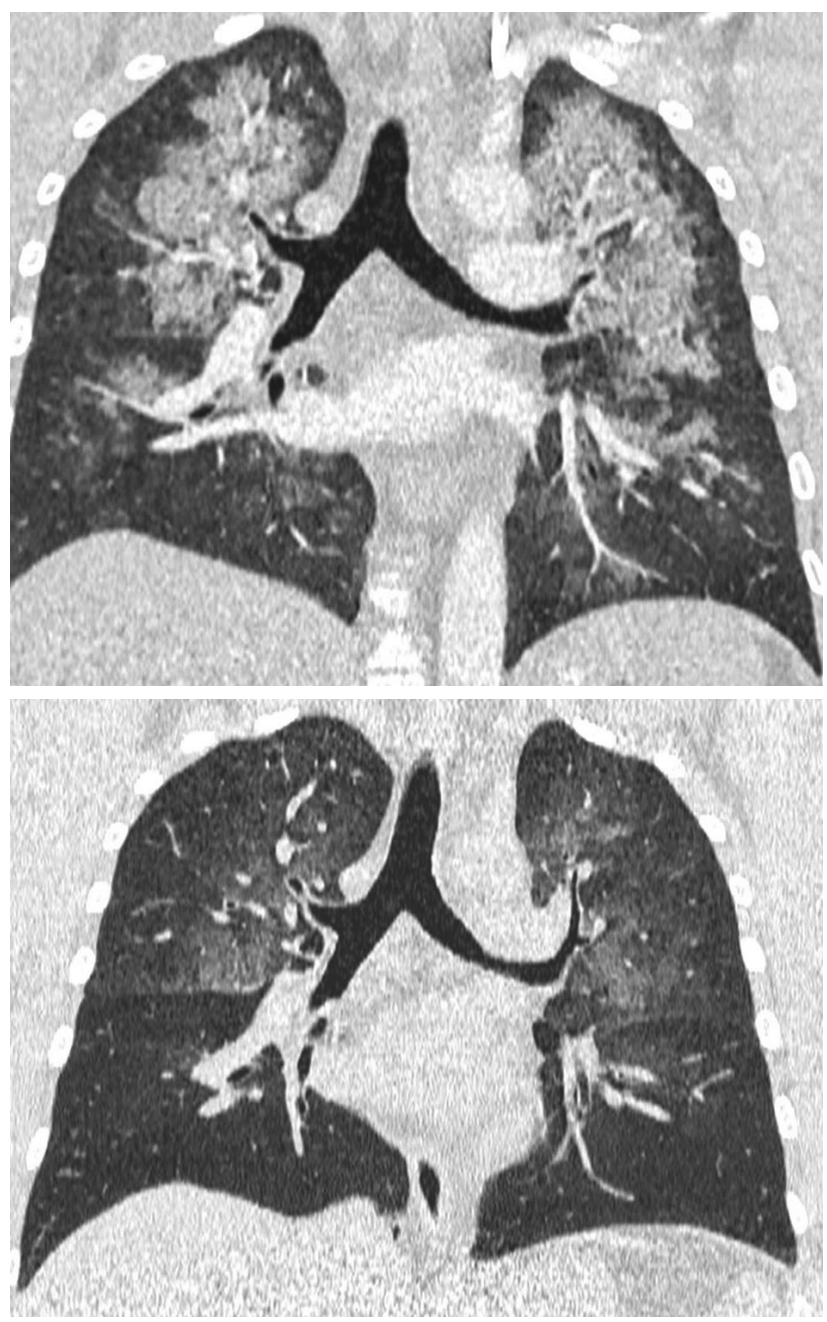

Figure 1. A 25-year-old man with NPPE. In computed tomography alveolar consolidations which were denser in the central interstitial area of both lungs are seen (A). Following the treatment, decreased consolidations are seen (B). 
mechanical ventilation and $8 \mathrm{mg}$ dexamethasone and $20 \mathrm{mg}$ furosemide were given to the patient taken to intensive care unit. Following the treatments, both symptomatic and radiological improvement was seen (Figure 1).

\section{CASE 2}

A 28-year-old, obese (BMI: 35,6), ASA score II man was admitted to hospital due to cholelithiasis and operated. Preoperatively, his chest examination results were normal, and a chest radiogram indicated clear lung fields. The patient was ventilated with a $500 \mathrm{ml}$ tidal volume in order to maintain 15 respirations per minute in a volume control mode. The operation lasted for about 90 minutes. In the operation, $1200 \mathrm{~mL}$ crystalloid $(0.9 \% \mathrm{NaCl})$ infusion was made. The procedure was concluded without any complications. Following extubation, severe agitation, bronchospasm and inspiratory effort developed in the patient. In recovery room, negative pressure pulmonary edema was suspected due to auscultation of common rales in both lungs and with 2-4 L/min oxygen saturation values of $91 \%$ at postoperative tenth minutes. In the first blood gas sample $\mathrm{pH}: 7.31, \mathrm{pO}_{2}: 52$ $\mathrm{mmHg}, \mathrm{PCO}_{2}: 31 \mathrm{mmHg}, \mathrm{HCO}_{3}: 19 \mathrm{mmol} / \mathrm{L} \mathrm{Lac}-$

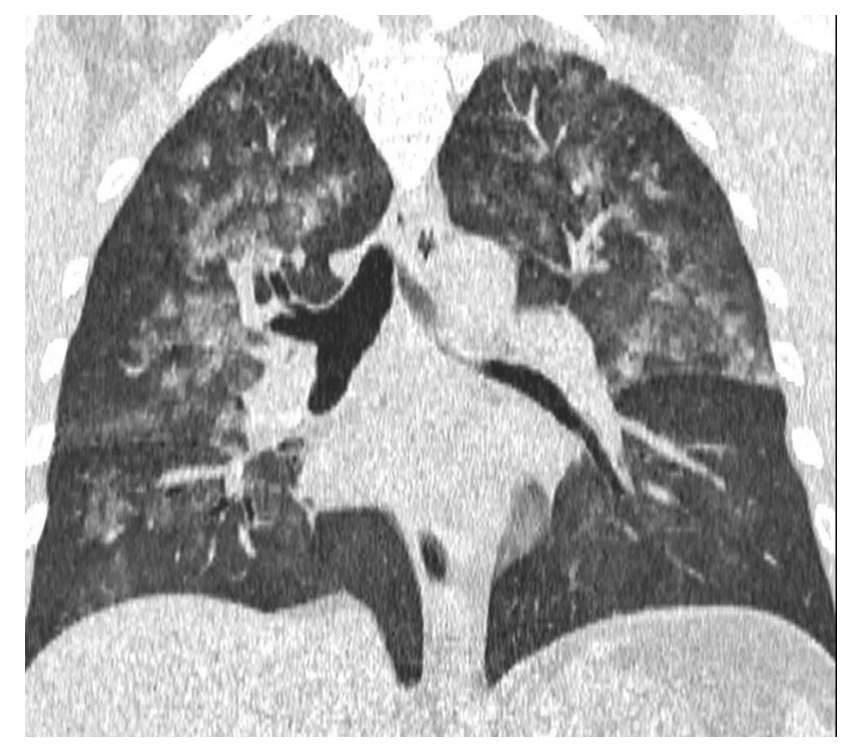

Figure 2. A 28-year-old man with NPPE. Alveolar consolidations are prominent in the central interstitial area of both lungs. tate: $1.5 \mathrm{mmol} / \mathrm{L}$ in recovery room. Together with oxygen support, non-contrast computed tomography was obtained. There were ground-glass opacifications and alveolar consolidations which were denser in the central interstitial area of both lungs (Figure 2). The patient was given oxygen and taken to intensive care unit for postoperative follow-up. Noninvasive mechanical ventilation and $8 \mathrm{mg}$ dexamethasone and $20 \mathrm{mg}$ furosemide treatments were given to the patient taken to the intensive care unit. Following the treatments, both symptomatic and radiological improvement was seen. The patient did not need intubation and we applied NIMV for positive pressure ventilation strategy. The patient was discharged from the intensive care unit after two days of intermittent NIMV application.

\section{DISCUSSION}

Although NPPE is a rare complication with a rate of $0.094 \%$ in general anesthesia protocol, this rate increases over $11 \%$ in patients with postoperative acute upper airway obstruction. In its pathogenesis, it has been reported that intense inspiratory effort against an obstructed airway leads to pulmonary edema (Figure 3$)^{1,2}$. The range of normal inspiratory pleural pressure varies between (-2) $-(-5) \mathrm{CmH}_{2} \mathrm{O}$; however, inspiratory pleural nega-

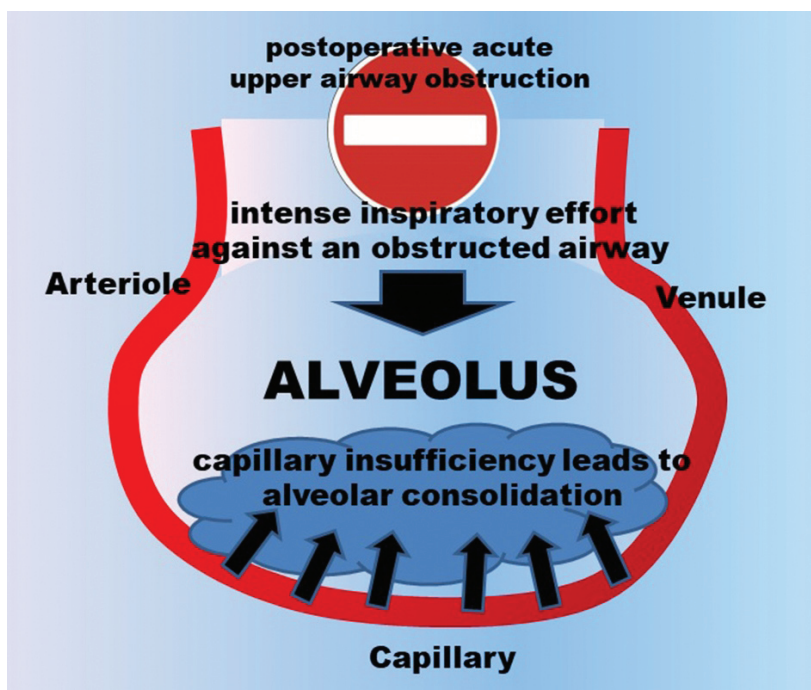

Figure 3. Intense inspiratory effort against an obstructed airway causes pulmonary edema. 
tive pressure may increase up to about $100 \mathrm{~cm}$ $\mathrm{H}_{2} \mathrm{O}$ during the difficult inspiratory effort against obstruction $^{3,4}$. Venous return to right heart increases, left ventricular output decreases, right ventricular dilatation, shifting to the left in the interventricular septum and left ventricular diastolic dysfunction develop owing to the increased pressure. It has been reported that, in this case, microvascular circulation fails, capillary insufficiency develops, alveolar fluid flow increases, and, eventually pulmonary edema develops $s^{3,5}$. Adrenergic discharge, depending on anxiety with hypoxia, makes the case even worse ${ }^{6,7}$. In its etiology, croup, epiglottitis, previous oropharyngeal surgery, short neck, obesity, foreign materials, tumors, non-viscous tracheal secretions are also taken into consideration.

However, the most frequently known cause of NPPE in adults is laryngospasm after extubation ${ }^{8,9}$. It has been reported that NPPE is more common in healthy young adults who have well-developed inspiratory muscles and can generate this pressure easily ${ }^{10}$. We think that our cases were also healthy young patients, post-extubation laryngospasm and hypoxia contributed to this situation.

Cascade et al. ${ }^{4}$ reported that NPPE has to be suspected postoperatively in young patients with bilateral central pulmonary edema, increased vascularity, and normal cardiothoracic ratio. For these patients, it is important to make a proper differential diagnosis among massive fluid transfusion, cardiogenic pulmonary edema, anaphylaxis, neurogenic pulmonary edema, and acute respiratory distress syndrome in terms of treatment choice ${ }^{11-13}$. There was no history of allergy in our patients. Postoperative cardiovascular system examinations were normal. Since posterior anterior (PA) chest X-ray revealed bilateral central interstitial infiltrations and normal cardiothoracic ratio, there were alveolar type consolidations in upper lobes of bilateral lung parenchyma, lack of massive liquid transfusion during surgery and a rapid recovery pattern with corticosteroid treatment confirmed the diagnosis of NPLE. The treatment is the breakage of the vicious cycle by correcting of hypoxia ${ }^{14}$. Proper diagnosis provides the choice of appropriate treatment and rapid recovery.

In conclusion, NPPE is a rare complication of general anesthesia affecting young adults. In patients with sudden onset of respiratory distress in the postoperative period, alveolar consolidations, which are more prominent in the upper lobes of both lungs, should suggest the diagnosis of NPPE in order to select the appropriate treatment.

\section{REFERENCES}

1. Westreich R, Sampson I, Shaari CM, Lawson W. Negativepressure pulmonary edema after routine septorhinoplasty: discussion of pathophysiology, treatment, and prevention. Arch Facial Plast Surg. 2006;8:8-15. [CrossRef]

2. Bisinotto FM, Cardoso Rde P, Abud TM. Acute pulmonary edema associated with obstruction of the airways. Case report. Rev Bras Anestesiol. 2008;58:165-71. [CrossRef]

3. Willms D, Shure D. Pulmonary edema due to upper airway obstruction in adults. Chest. 1988;94:1090-2. [CrossRef]

4. Cascade PN, Alexander GD, Mackie DS. Negative-pressure pulmonary edema after endotracheal intubation. Radiology. 1993;186:671-5. [CrossRef]

5. Orlowski JP. Drowning, near-drowning, and ice-water submersions. Pediatr Clin North Am. 1987;34:75-92. [CrossRef]

6. Schwartz DR, Maroo A, Malhotra A, Kesselman H. Negative pressure pulmonary hemorrhage. Chest. 1999; 115:1194-7. [CrossRef]

7. Golden FS, Tipton MJ, Scott RC. Immersion, near-drowning and drowning. Br J Anaesth. 1997;79:214-5. [CrossRef]

8. Tami TA, Chu F, Wildes TO, Kaplan M. Pulmonary edema and acute upper airway obstruction. Laryngoscope. 1986;96:506-9. [CrossRef]

9. Omar H, Kolla J, Anand A, Nel W, Mangar D, Camporesi E. Negative pressure pulmonary edema in the prone position: a case report. Cases J. 2009;2:8594. [CrossRef]

10. Myers CL, Gopalka A, Glick D, Goldman MB, Dinwiddie SH. A case of negative-pressure pulmonary edema after electroconvulsive therapy. J ECT. 2007;23:281-3. [CrossRef]

11. Deepika K, Kenaan CA, Barrocas AM, Fonseca JJ, Bikazi GB. Negative pressure pulmonary edema after acute upper airway obstruction. J Clin Anesth. 1997;9:403-8. [CrossRef]

12. Krodel DJ, Bittner EA, Abdulnour R, Brown R, Eikermann $M$. Case scenario: acute postoperative negative pressure pulmonary edema. Anesthesiology. 2010;113:200-7. [CrossRef]

13. Gluecker T, Capasso P, Schnyder P, et al. Clinical and radiologic features of pulmonary edema. Radiographics. 1999;19:1507-33. [CrossRef]

14. Bhattacharya M, Kallet RH, Ware LB, Matthay MA. Negative-Pressure Pulmonary Edema. Chest. 2016;150:92733. [CrossRef] 